\title{
Driving cycle based battery rating selection and range analysis in EV applications
}

\author{
Jyothi P. Phatak ${ }^{1}$, L. Venkatesha ${ }^{2}$, C. S. Raviprasad ${ }^{3}$ \\ ${ }^{1,3}$ Department of Electrical and Electronics Engineering, BMS College of Engineering, Bengaluru, India \\ ${ }^{2}$ Tarun Technologies, Bangalore, India
}

\begin{tabular}{|c|c|}
\hline Article Info & ABSTRACT \\
\hline Article history: & \multirow{10}{*}{$\begin{array}{l}\text { The energy consumption of electric vehicles (EVs) depends on traffic } \\
\text { environment, terrain, resistive forces acting on vehicle, vehicle } \\
\text { characteristics and driving habits of driver. The battery pack in EV is the } \\
\text { main energy storage element and the energy capacity determines the range of } \\
\text { vehicle. This paper discusses the behavior of battery when EV is subjected to } \\
\text { different driving environments such as urban and highway. The battery rating } \\
\text { is selected based on requirement of driving cycle. The MATLAB/Simulink } \\
\text { model of battery energy storage system (BESS) consisting of battery, } \\
\text { bidirectional DC/DC converter and electric propulsion system is built. The } \\
\text { simulation is carried out and the performance of BESS is tested for standard } \\
\text { driving cycles which emulate actual driving situations. It has been shown } \\
\text { that, the amount of the energy recovered by battery during deceleration } \\
\text { depends on the amount of regenerative energy available in the driving cycle. } \\
\text { If the battery recovers more energy during deceleration, the effective energy } \\
\text { consumed by it reduces and the range of the vehicle increases. }\end{array}$} \\
\hline Received Jun 8, 2020 & \\
\hline Revised Mar 3, 2021 & \\
\hline Accepted Apr 17, 2021 & \\
\hline Keywords: & \\
\hline Battery & \\
\hline Driving cycle & \\
\hline Electric vehicle & \\
\hline Range & \\
\hline Regenerative energy & \\
\hline
\end{tabular}

This is an open access article under the CC BY-SA license.

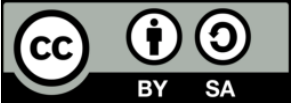

\section{Corresponding Author:}

Jyothi P Phatak

Department of Electrical and Electronics Engineering

BMS College of Engineering

Bull Temple Road, Basavanagudi, Bengaluru - 560019, India

Email: jyothip.pej15@bmsce.ac.in

\section{INTRODUCTION}

The automobiles used around the world has affected and continues to affect environment and human life adversely. The problems such as air pollution, global warming, and rapid exhaustion of petroleum resources are of primary concern [1]. Some of the conditions such as climate change, advances in renewable energy, quick urbanization, data capture and analysis, battery chemistry have led to the start of electric vehicle technology in the market [2]. The Indian government under national electric mobility mission plan (NEMMP), has taken initiatives to promote electric and hybrid electric vehicles in the country [3].

Energy storage system (ESS) is considered as the heart of EV. The energy storage technologies decide the future development and commercialization of EVs. These technologies are assessed in terms of parameters and factors of battery such as, voltage, energy capacity, state of charge (SOC), weight/size, cost, lifetime, charge and discharge current capacity, etc. The battery operating conditions are characterized with the help of these parameters and factors. These describe the manufacturer specifications. The range of the vehicle is determined by the wh/km consumed by the vehicle and the energy capacity of battery pack. Sizing the energy source of hybrid vehicle depending on statistical explanation of driving cycles is discussed in [4]. The battery capacity is computed by considering the average power of driving cycle. A convex optimization 
technique is used for power split optimization and then optimal sizing of battery and ultracapacitor (UC) is carried out in [5].

The performance of bidirectional DC/DC converter is analyzed with pi and sliding mode controller in the paper [6]. The proposed system can be utilized in electric vehicles and small grids. The THD of EV motor drive can be minimized with digital signal controllers as compared to conventional control systems. This is well explained in [7]. The regenerative braking concept is developed experimentally for EV by using enhanced bidirectional DC/DC converter in [8]. This fundamental experimentation helps to understand the behavior of battery during vehicle deceleration. The communication and car learing based novel power management architecture is introduced in [9]. This architecture is based on smart data base concept. The flux switching machine (FSM) concept is very well explained in [10] as a high torque EV drive. It is having a double rotating frequency and is an advanced form of synchronous machine. This study helps in the design on traction drive for EVs. The frequency response method based sliding mode control technique is applied for DC/DC buck converter in [11]. By integrating the basic converters, non isolated triport converter is built for renewable energy applications [12]. The power flow between source and load with different switching patterns can be achieved with the help of this converter. The battery management system adopted for electric bike monitors individual cell voltage with a minimum average error of $0.824 \%$ [13]. This technique helps in developing energy management strategy for battery energy storage system. A five-level neutral point clamped inverter which feeds the induction motor (IM) drive is built. The FOC is incorporated by sliding mode speed regulator. This is very well explained in [14]. The sizing of battery based on the energy requirement for one charge is explained in [15]. Filter based and optimization-based sizing of battery and ultracapacitor is discussed in [16]. The procedure to compute the traction motor ratings for EV application is well explained in [18]-[20]. This forms a foundation to compute the ratings of traction motor for EV. Hybrid energy storage system (HESS) sizing methodologies consisting of battery and supercapacitor are well documented in [21]. For demand response based on internet of electric vehicles, efficient and secured energy trading frame work has been proposed by combining contract theoretical modelling, consortium blockchain and computational intelligence [22].

The paper is organized into 8 sections. The second section explains about the driving cycles which are required to test the system to assess its performance. The third section explains the selection of traction motor which satisfies the driving cycle requirements and performance specifications of vehicle. The EV load emulation is explained in the fourth section. Selection of battery rating is explained in section five. The sixth section discusses about simulation of battery energy storage system (BESS) using MATLAB/Simulink. The results and discussions are explained in section seven. The conclusion and future scope are discussed in section eight.

\section{DRIVING CYCLE}

Driving cycles are required to evaluate the performance of EV in various ways. In this work these cycles are used as test signals to evaluate the performance of BESS. The driving cycles depend on traffic environment, terrain and driving habits of driver. However certain set of standard cycles are considered in this work which emulate actual driving environments. The details about few sample cycles among the set are given in Table 1 .

Table 1. Driving cycle details

\begin{tabular}{cccccccc}
\hline $\begin{array}{l}\text { Driving } \\
\text { cycle }\end{array}$ & $\begin{array}{l}\text { Distance } \\
(\mathrm{km})\end{array}$ & $\begin{array}{l}\text { Time } \\
(\mathrm{sec})\end{array}$ & $\begin{array}{l}\text { +ve peak } \\
\text { current }(\mathrm{A})\end{array}$ & $\begin{array}{l}\text {-ve peak } \\
\text { current }(\mathrm{A})\end{array}$ & $\begin{array}{c}\text { Average } \\
\text { current }(\mathrm{A})\end{array}$ & $\begin{array}{l}\text { Wh/ } \\
\mathrm{km}\end{array}$ & $\begin{array}{l}\text { Regenerative energy } \\
\text { available in the cycle }(\text { wh) }\end{array}$ \\
\hline Tata 1 & 1.85 & 260 & 65 & -81 & 9 & 137 & 83 \\
Tata 2 & 1.8 & 200 & 121 & -102 & 12 & 145 & 150 \\
UDDS & 4.24 & 300 & 93 & -63 & 23 & 172 & 80 \\
EUDC & 4.41 & 195 & 185 & -59 & 47 & 218 & 95.3 \\
\hline
\end{tabular}

The "tata1" and "tata2" are practical driving cycles obtained in Bangalore urban area. This is one of the samples which emulates the real-world driving pattern in the city. Data collection is a significant step in getting this cycle [17]. Most of the cars have an on-board diagnostic (OBD), a computer-based system which contains electronic control unit (ECU) which receives inputs from various sensors to control the actuators to get the desired information. To obtain the data for the driving cycle, the OBD-II adapter is connected to the OBD -II port in the car. The OBD software communicated with the car via USB and presented the diagnostic information. The data obtained from the OBD is stored in a readable format such as in MS EXCEL. The driving cycle obtained is shown in Figure 1. In order to make the simulation faster and easier, this driving 
cycle is split into two parts. "Tata1" and "tata2" driving cycles. The details are shown in Table 1. One of the samples of driving cycles is shown in Figure 2.

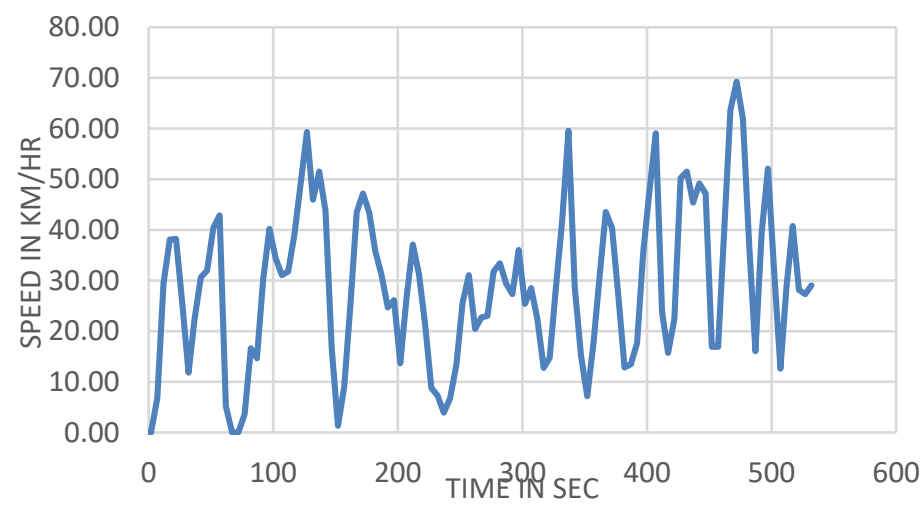

Figure 1. Practical driving cycle (tata1 and tata2) (urban driving)

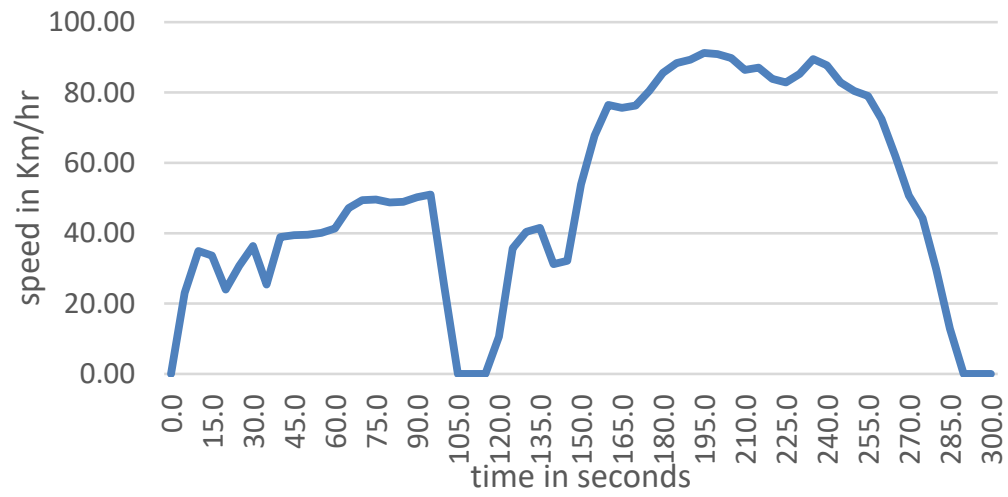

Figure 2. UDDS driving cycle (urban driving)

\section{SELECTION OF TRACTION MOTOR}

The work has been carried out on selection of traction motor for EV and details about this is explained in paper [23]. Ratings of the motor computed in [23] are mentioned in Table 2.

Table 2. Specifications of motor

\begin{tabular}{ll}
\hline Motor Type & Three phase Squirrel Cage IM \\
\hline Specifications & $15 \mathrm{KW}, 200 \mathrm{~V}, 4$ pole, 2500 RPM \\
Torque (Nm) & $390 \mathrm{Nm} @ 2500 \mathrm{RPM}$ \\
Power (KW) & $100 @ 2500-8000 \mathrm{RPM}$ \\
Moment of Inertia & $0.107 \mathrm{Kgm}^{2}$ \\
\hline
\end{tabular}

\section{EV LOAD EMULATION}

Electric propulsion system of BESS consists of wheels, mechanical transmission, traction drive and inverter. It is a complex system consisting of both electrical and mechanical components. It is approximated by an equivalent current load. This acts as a load to BESS giving feel of virtual electric vehicle. The current load is obtained as follows.

The dynamic model of 3 phase Induction motor (IM) is constructed with the help of MATLAB Simulink as shown in Figure 3 [24]. This model considers the specifications of IM mentioned in Table 2 which is computed in paper [23]. Sample driving cycles discussed in section 2 are given as speed references to input. The $\mathrm{V} / \mathrm{F}$ technique is applied to generate sinusoidal three phase supply of proper voltage and 
frequency to excite the motor. The load torque applied to the motor includes the rolling friction force and aerodynamic drag force of $\mathrm{EV}$ assuming a level ground. The product $\mathrm{J} * \mathrm{dw} / \mathrm{dt}$ ( $\mathrm{J}$ is the effective moment of inertia of the vehicle and machine together) provides the accelerating force. The open loop simulation is done. The input power and energy of induction motor are obtained by capturing the instantaneous values of phase voltage and phase currents. Since the actual inverter model is not considered here, the DC current from the inverter corresponding to each driving cycle is obtained using the (1). This represents the entire vehicle load. The graphs representing the speed, load torque and Direct Current (DC) current for one of the sample driving cycles is shown in Figure 4, Figure 5 and Figure 6 respectively. The efficiency of the inverter is assumed as 0.9 .

$$
\mathrm{I}_{\mathrm{DC}}=\left(\frac{\frac{\sqrt{3} \mathrm{~V}_{\mathrm{L}} \mathrm{I}_{\mathrm{L}} \cos (\mathrm{phi})}{\mathrm{V}_{\mathrm{DC}}}}{0.9}\right)
$$

where $\mathrm{V}_{\mathrm{L}}=$ RMS line to line voltage of motor $\mathrm{I}_{\mathrm{L}}=$ RMS line to line current of motor. $\mathrm{V}_{\mathrm{DC}}=\mathrm{DC}$ bus voltage, phi $=$ cosine of angle between $\mathrm{V}_{\mathrm{L}}$ and $\mathrm{I}_{\mathrm{L}}$.

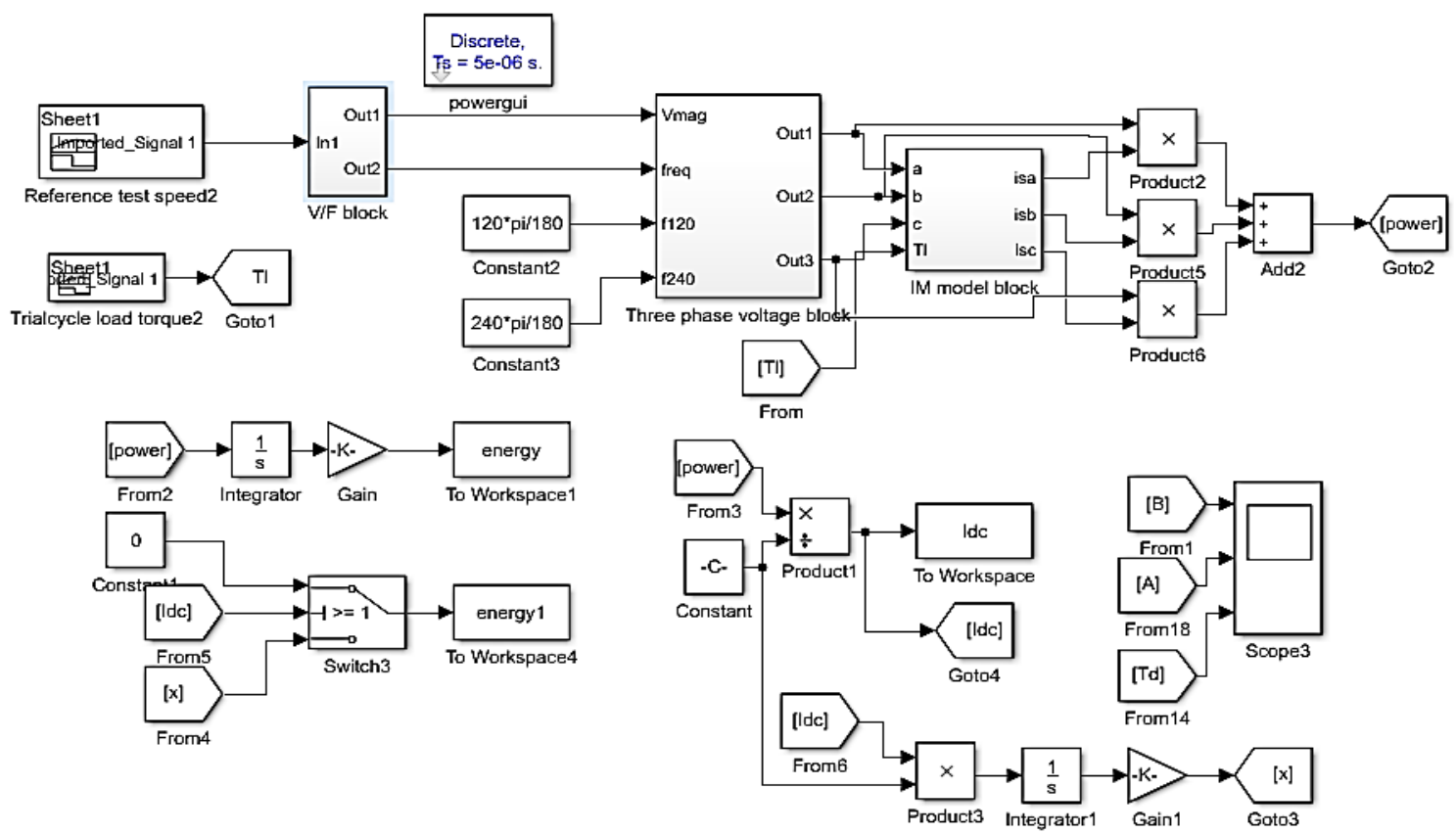

Figure 3. Dynamic model of 3 phase induction motor (Simulink model)

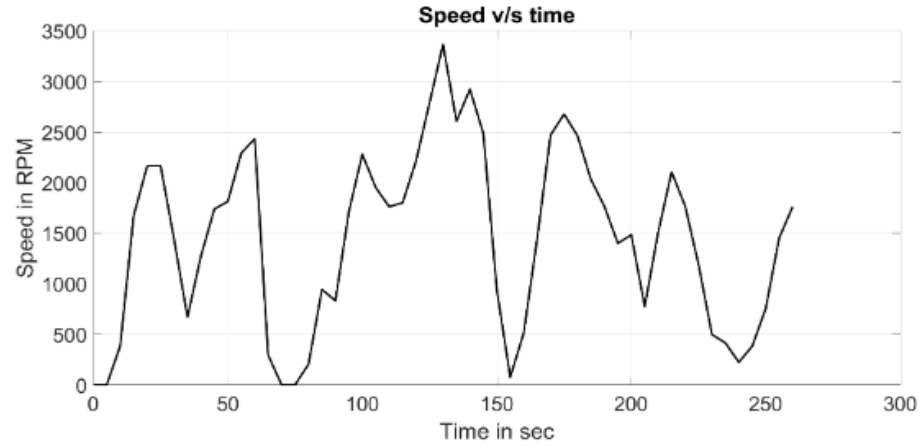

Figure 4. Speed v/s time graph 


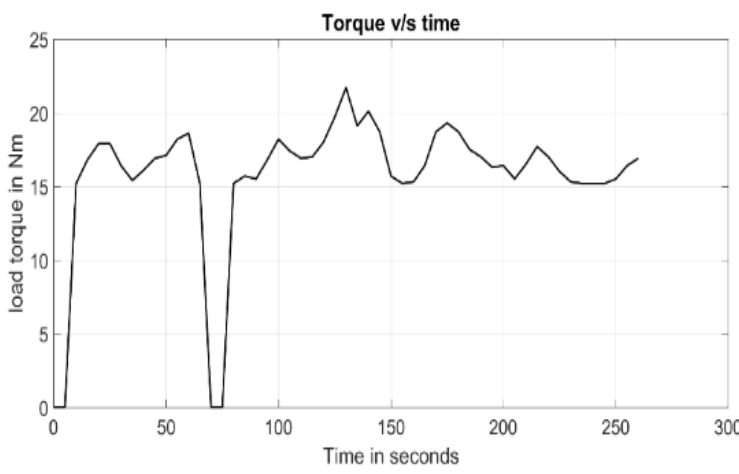

Figure 5. Torque v/s time graph

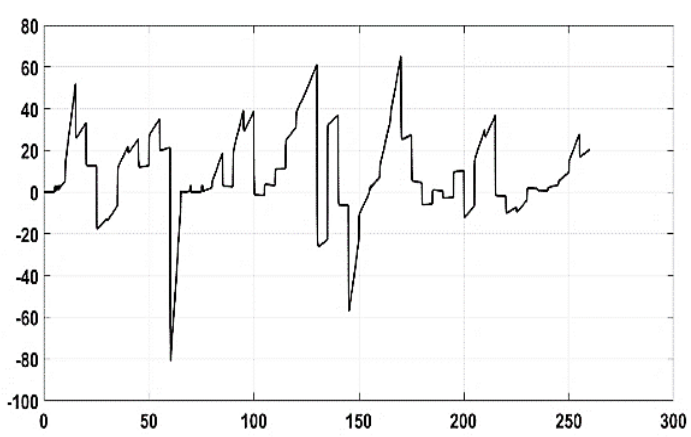

Figure 6. DC current of the inverter v/s time graph

\section{SELECTION OF BATTERY RATING FOR BESS}

The battery is connected to vehicle via bidirectional DC DC converter. The bus voltage is selected as $400 \mathrm{~V}$ [23]. The converter acts in a boost mode during acceleration of vehicle and steps up the voltage from $250 \mathrm{~V}$ to $400 \mathrm{~V}$. It acts in a buck mode during deceleration and steps down the voltage from $400 \mathrm{~V}$ to $250 \mathrm{~V}$.

The selection of battery ampere-hour for BESS depends on the average and peak current requirements of driving cycle and the range the vehicle it has to cover. The battery rating is computed with either of the methods: a) average current method, and b) $\mathrm{Wh} / \mathrm{km}$ method.

\subsection{Average current method}

Table 1 .

The "tata1" driving cycle is considered for the calculations. The details about this cycle are given in

Distance travelled by "tata1" $=1.85 \mathrm{~km}$

Cycle duration $(\mathrm{T})=260 \mathrm{sec}$

Range of the vehicle $=250 \mathrm{~km}$

Number of cycles required $(n)=\frac{250}{1.85}=135.14$

Average battery current $=$ Input current of boost converter $($ Ibat $)=\frac{\text { Io }}{(1-\mathrm{D})}=15 \mathrm{~A}$

Ah of battery $=\frac{\mathrm{I}_{\mathrm{bat}} * \mathrm{~T} * \mathrm{n}}{3600}=146 \mathrm{Ah}$

$\mathrm{KWH}$ of battery $=250 * 146=36.5 \mathrm{kwh}$ where, battery voltage is $250 \mathrm{~V}$.

\subsection{Wh/km method}

The watthour/km for "tata 1 " calculated is shown in Table 1.

The watthour $/ \mathrm{km}$ for "tata1" $=137 \mathrm{wh} / \mathrm{km}$

The total kwh of the battery required to cover a range of $250 \mathrm{~km}=250 * 137=34.3 \mathrm{kwh}$

$\mathrm{Ah}$ of the battery $=($ total $\mathrm{wh}$ of battery/battery voltage $)=(34.3 * 1000) / 250=137 \mathrm{Ah}$

The kilowatt-hour calculated using above two methods give similar values. The rating of battery for remaining driving cycles are calculated with similar procedure. The ratings are given in Table 3 . The "trial cycle" requires the highest battery capacity among all the values calculated and it is $62.5 \mathrm{kwh}$. If the same battery is utilized for other driving cycles, the range of the vehicle gets increased.

Table 3. Rating of battery for different driving cycles

\begin{tabular}{cc}
\hline Type of driving cycle & Battery rating \\
\hline Tata 1 & $140 \mathrm{Ah}, 250 \mathrm{~V}, 35 \mathrm{kwh}$ \\
Tata 2 & $150 \mathrm{Ah}, 250 \mathrm{~V}, 37.5 \mathrm{kwh}$ \\
UDDS & $172 \mathrm{Ah}, 250 \mathrm{~V}, 43 \mathrm{kwh}$ \\
Variable speed cycle & $224 \mathrm{Ah}, 250 \mathrm{~V}, 56 \mathrm{kwh}$ \\
Trial cycle & $250 \mathrm{Ah}, 250 \mathrm{~V}, 62.5 \mathrm{kwh}$ \\
EUDC & $218 \mathrm{Ah}, 250 \mathrm{~V}, 54.5 \mathrm{kwh}$ \\
Constant speed cycle & $192 \mathrm{Ah}, 250 \mathrm{~V}, 48 \mathrm{kwh}$ \\
\hline
\end{tabular}

\section{SIMULATION OF BESS}

The battery energy storage system consists of lithium ion battery, bidirectional DC/DC converter, controller and current load. The battery is interfaced with DC bus via converter. The inverter, IM, mechanical 
transmission and vehicle are effectively represented by a equivalent current load. The block diagram and simulation model are depicted in Figure 7 and Figure 8 respectively. Generic model of battery from simulink library is considered for simulation. This model considers the battery ratings computed in section 5 . The simulation model has two subsystems, "bidirectional DC/DC converter" block and "controller" block. The first block operates as a boost converter during acceleration mode and as a buck converter during deceleration mode. The controller consists of two PID controllers each for boost operation and buck operation of converter respectively. The PID controller corresponding to boost operation is shown in Figure 9.

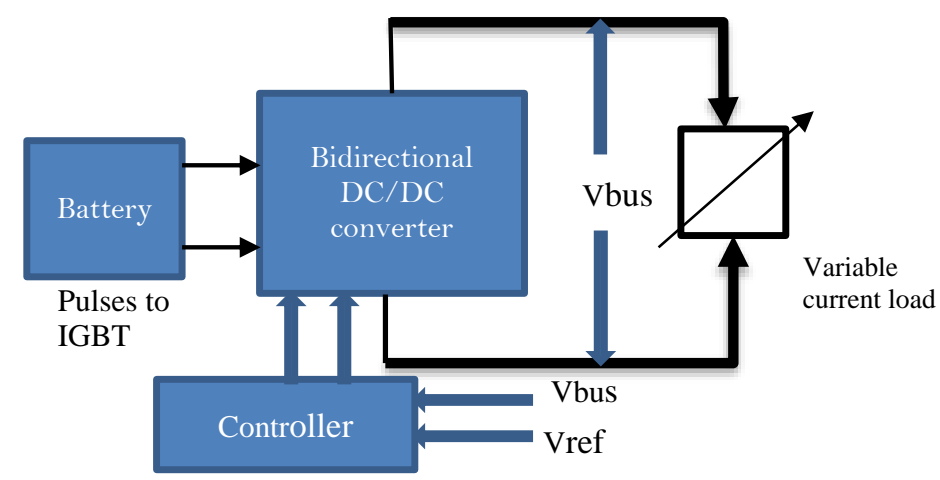

Figure 7. Block diagram of BESS

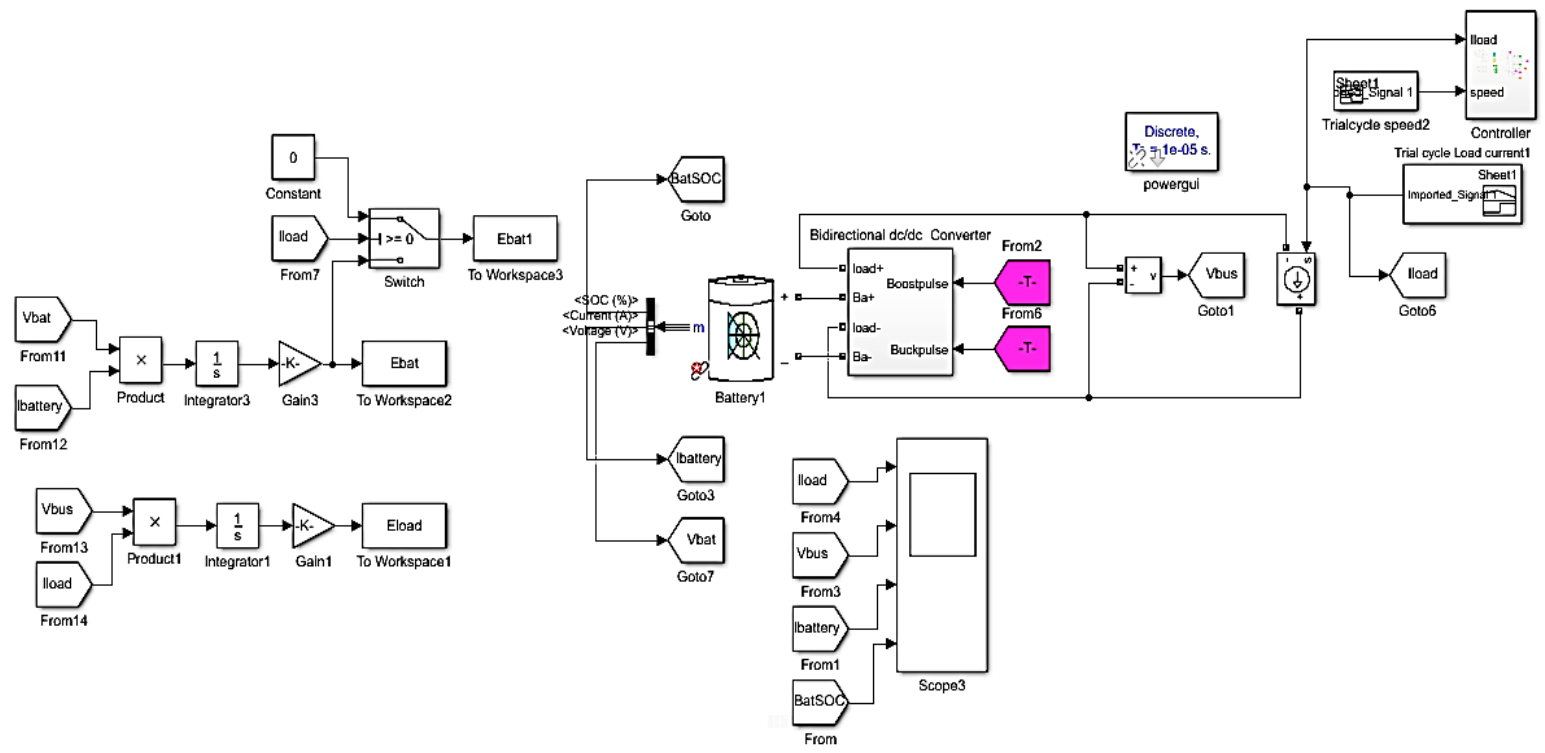

Figure 8. Simulink model of BESS 


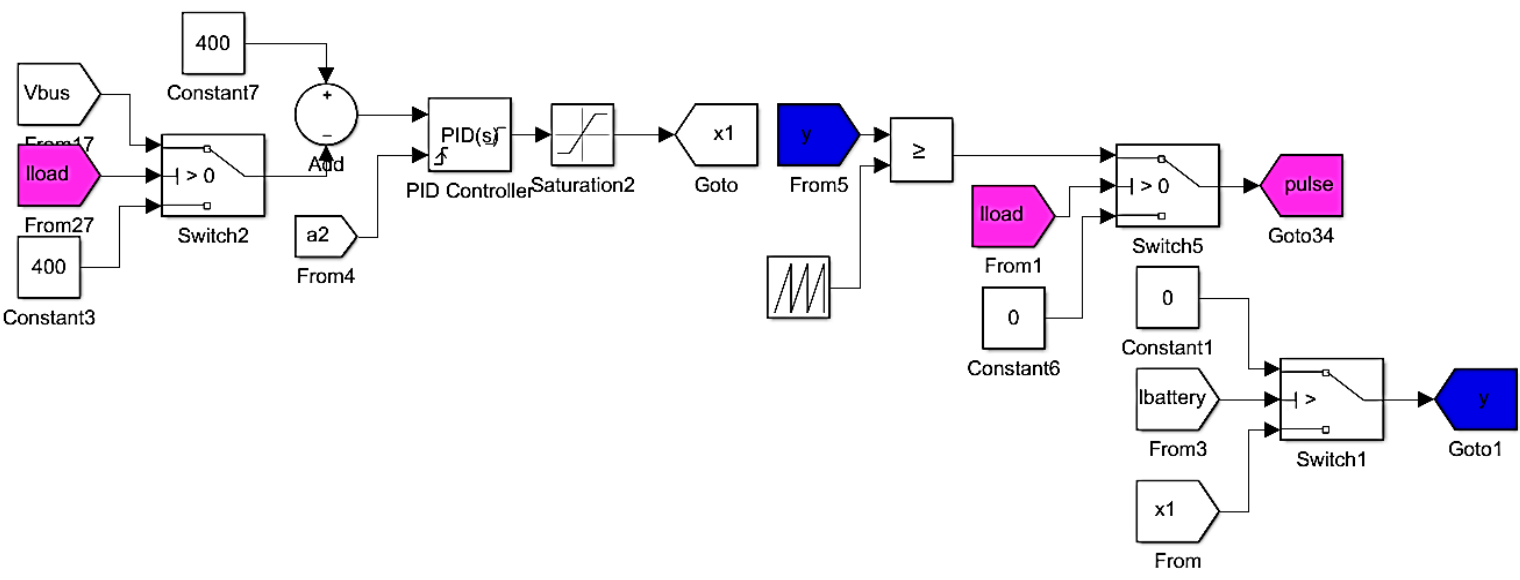

Figure 9. PID controller and current control

\subsection{Control strategy}

The controller identifies the modes of operation of vehicle such as acceleration, deceleration, rest and constant speed by detecting the load current and speed of the vehicle. The controlling parameters of BESS are, SOC of battery, battery current and DC bus voltage. When the vehicle is at rest, the battery should be charged to its maximum SOC. The controller makes sure that the SOC is equal to its maximum value.

During acceleration mode, battery supplies energy to the load through boost operation. The PID controller generates pulses to IGBT by regulating DC bus voltage and battery discharge current. The "controller" sends these IGBT pulses to boost converter by maintaining the SOC of battery in the safe limits. The maximum and minimum limits of SOC maintained by controller are $95 \%$ and $25 \%$ respectively. The schematic of BESS connected to variable current load during acceleration is shown in Figure 10. During the time Ton, the IGBT switch SW1 is ON and diode is OFF. The battery current flows through the inductor and switch SW1. The inductor current rises linearly and energy gets stored in the inductor. The load current is supplied by filter capacitor. The circuit corresponding to this mode is shown in Figure 11 (a). During Toff, diode gets forward biased and stored energy in the inductor gets transferred to filter capacitor and load. The load current is supplied by battery. The circuit corresponding to this mode is shown in Figure 11 (b).

Applying KVL and KCL to the circuit of Figure 11 (a), (SW1 is ON) [25].

$$
\begin{aligned}
& \mathrm{V}_{\mathrm{L}}=\mathrm{V}_{\mathrm{b}}-\mathrm{I}_{\mathrm{b}} \times\left(\mathrm{R}_{\mathrm{b}}+\mathrm{R}_{\mathrm{L}}+\mathrm{R}_{\mathrm{sw} 1}\right) \\
& \mathrm{I}_{\mathrm{L}}=\mathrm{I}_{\mathrm{b}} \\
& \mathrm{I}_{\mathrm{c}}=\mathrm{I}_{\text {Load }} \\
& \mathrm{V}_{\mathrm{c}}=\mathrm{V}_{\text {bus }}
\end{aligned}
$$

Applying KVL to the circuit of Figure 11(b), (SW1 is OFF).

$$
\begin{aligned}
& \mathrm{V}_{\mathrm{L}}=\mathrm{V}_{\mathrm{b}}-\mathrm{V}_{\text {bus }}-\mathrm{I}_{\mathrm{b}} \times\left(\mathrm{R}_{\mathrm{b}}+\mathrm{R}_{\mathrm{L}}+\mathrm{R}_{\mathrm{D}}\right) \\
& \mathrm{I}_{\mathrm{L}}=\mathrm{I}_{\mathrm{b}} \\
& \mathrm{I}_{\mathrm{c}}=\mathrm{I}_{\mathrm{b}}-\mathrm{I}_{\text {Load }} \\
& \mathrm{V}_{\mathrm{c}}=\mathrm{V}_{\text {bus }}
\end{aligned}
$$


RD

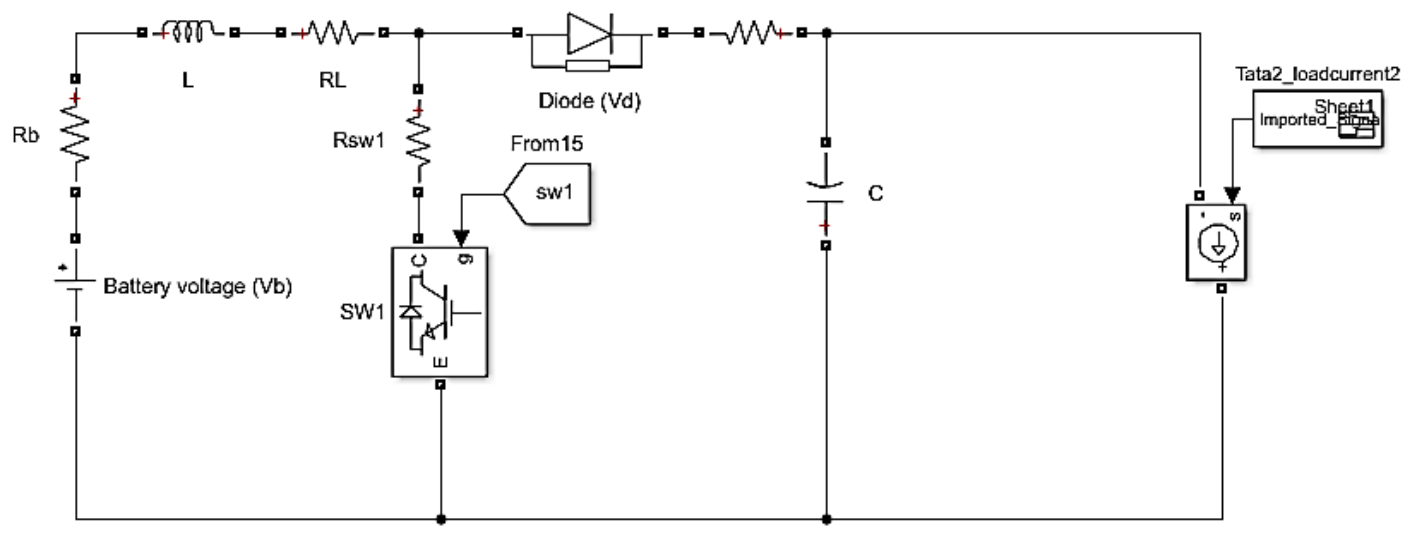

Figure 10. Battery Energy Storage System to current Load during acceleration mode

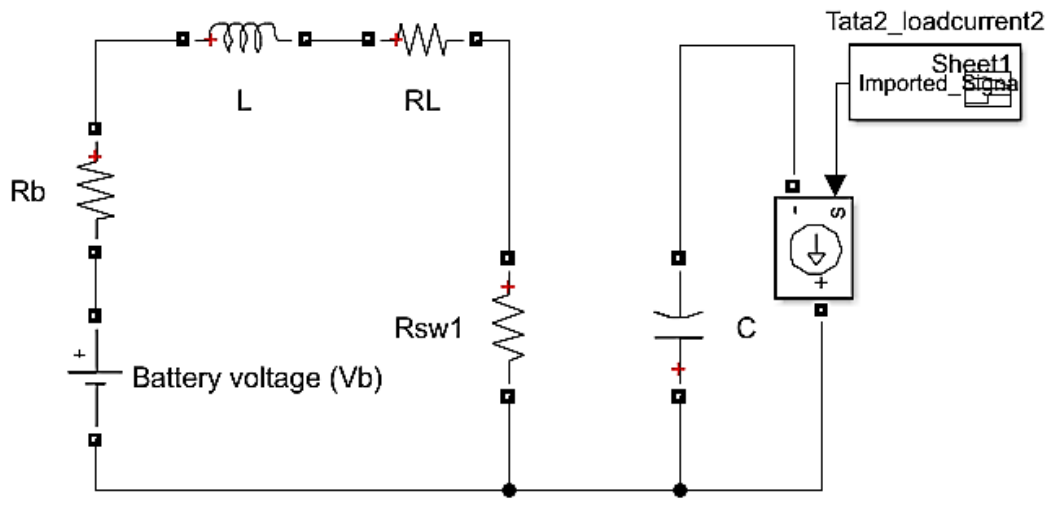

(a)

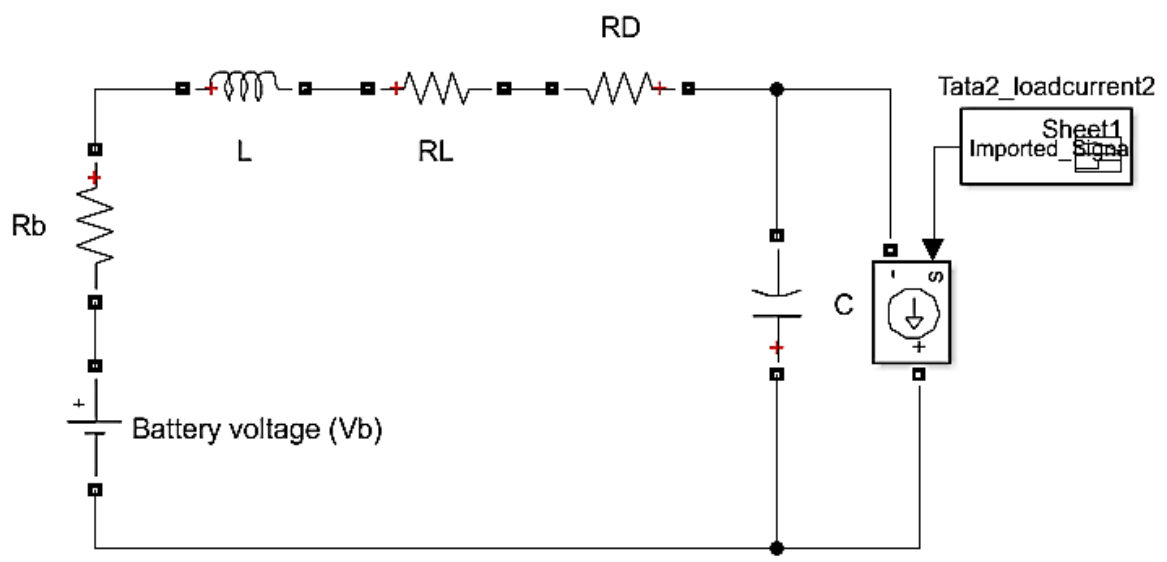

(b)

Figure 11. Converter in boost operation, (a) when SW1 is OFF \& diode is forward biased, (b)when SW1 is ON \& diode is reversed biased)

During deceleration mode, battery absorbs the regenerative energy from the vehicle through buck operation till the battery reaches its maximum SOC. The PID controller generates pulses to IGBT by regulating DC bus voltage. The "controller" sends these IGBT pulses to buck converter by maintaining the SOC of battery in the safe limits. The schematic of BESS connected to variable current load is shown in Figure 12. During Ton period, SW1 is ON, diode is OFF, the battery absorbs the energy from the load. The circuit related to this period is shown in Figure 13 (a). During Toff period, SW1 is OFF, diode gets forward 
biased and stored energy in the inductor freewheels through load and diode till the inductor current becomes zero. The circuit is shown in Figure 13 (b).

Applying KVL and KCL to circuit of Figure13 (a), (SW1 is ON, diode is OFF).

$\mathrm{V}_{\mathrm{L}}=\mathrm{V}_{\text {bus }}-\mathrm{V}_{\mathrm{b}}-\mathrm{I}_{\text {Load }}\left(\mathrm{R}_{\mathrm{sw} 1}+\mathrm{R}_{\mathrm{L}}+\mathrm{R}_{\mathrm{b}}\right)$

$\mathrm{I}_{\mathrm{L}}=\mathrm{I}_{\text {Load }}$

$\mathrm{V}_{\mathrm{c}}=\mathrm{V}_{\mathrm{b}}+\mathrm{I}_{\mathrm{b}} \mathrm{R}_{\mathrm{b}}$

$\mathrm{I}_{\mathrm{c}}=\mathrm{I}_{\text {Load }}-\mathrm{I}_{\mathrm{b}}$

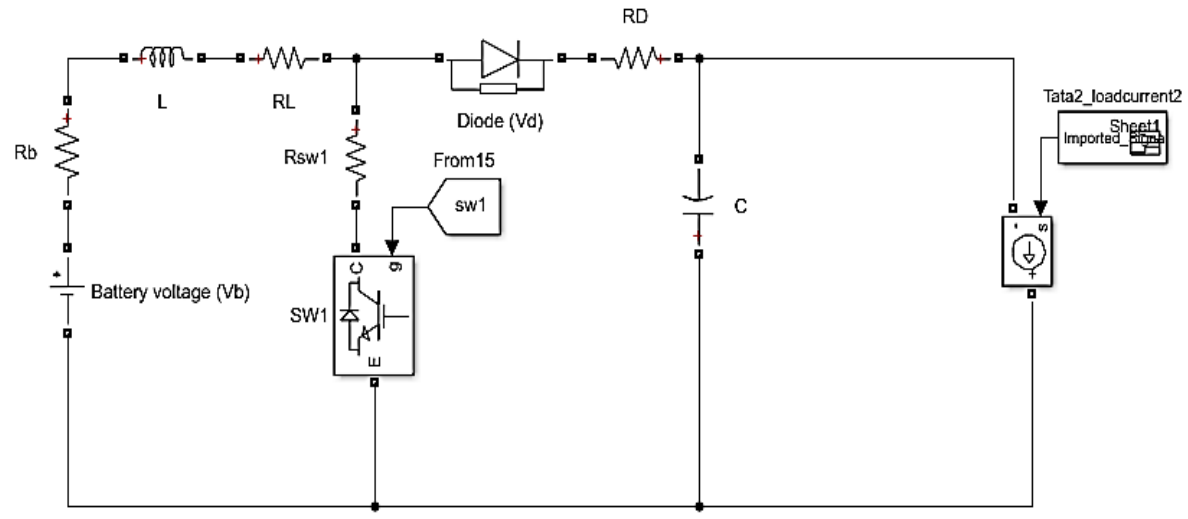

Figure 12. Battery energy storage system connected to current load during deceleration mode

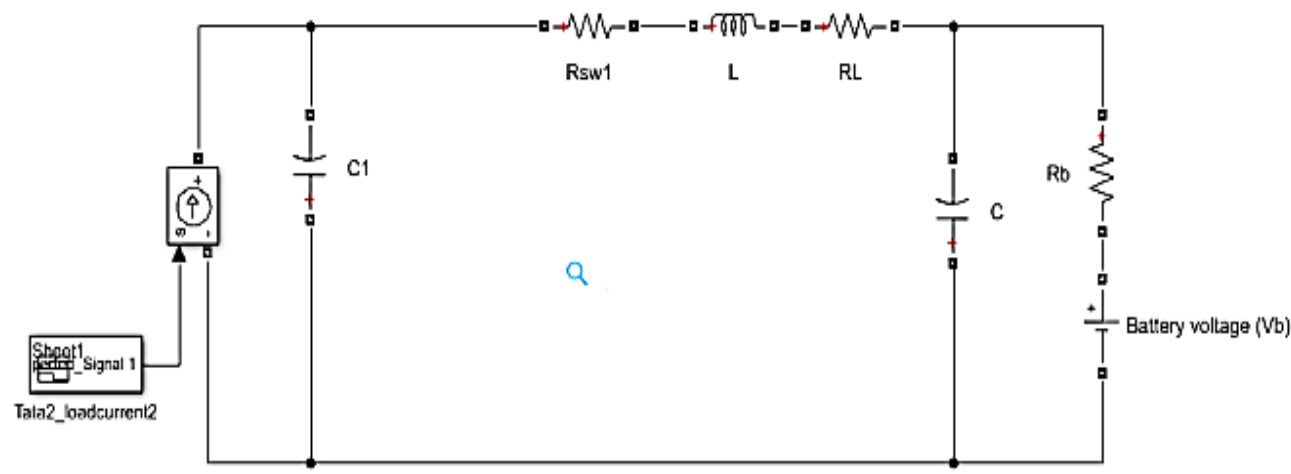

(a)

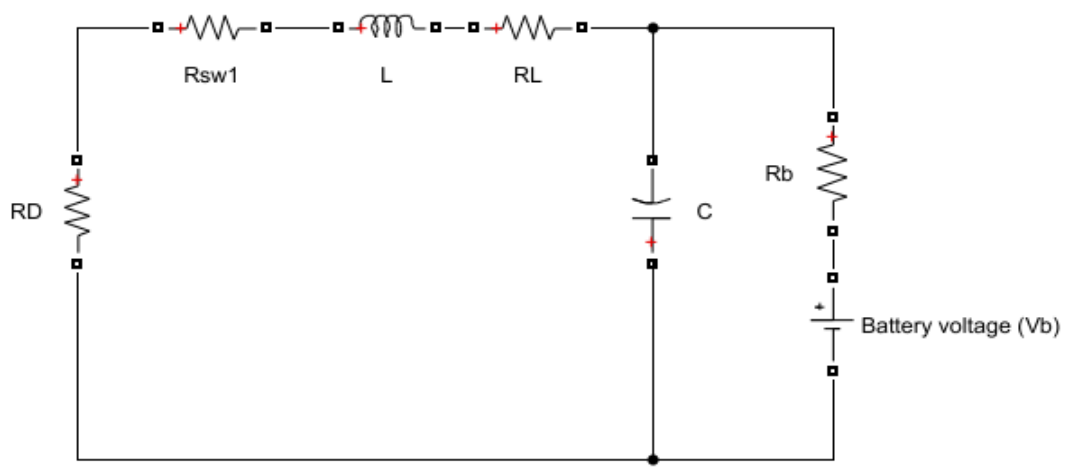

(b)

Figure 13. Buck operation, (a) SW1 is ON, diode is OFF), (b) SW1 is OFF, diode is ON 
Applying KVL and KCL to circuit of Figure 13 (b), (SW1 is OFF, diode is ON).

$$
\begin{aligned}
& \mathrm{V}_{\mathrm{L}}=-\mathrm{V}_{\mathrm{b}}-\mathrm{I}_{\text {Load }}\left(\mathrm{R}_{\mathrm{sw} 1}+\mathrm{R}_{\mathrm{L}}+\mathrm{R}_{\mathrm{b}}\right) \\
& \mathrm{I}_{\mathrm{L}}=\mathrm{I}_{\text {Load }} \\
& \mathrm{V}_{\mathrm{c}}=\mathrm{V}_{\mathrm{b}}+\mathrm{I}_{\mathrm{b}} \mathrm{R}_{\mathrm{b}} \\
& \mathrm{I}_{\mathrm{c}}=\mathrm{I}_{\text {Load }}-\mathrm{I}_{\mathrm{b}}
\end{aligned}
$$

$\mathrm{V}_{\mathrm{b}}=$ battery voltage; $\mathrm{Rb}=$ internal resistance of battery; $\mathrm{L}=$ filter inductor; $\mathrm{R}_{\mathrm{L}}=$ filter resistance; $\mathrm{R}_{\mathrm{D}}=$ diode forward resistance; $C=$ filter capacitance; $\mathrm{R}_{\mathrm{sw} 1}=\mathrm{on}$ state resistance of switch $\mathrm{SW} 1 ; \mathrm{R}_{\mathrm{sw} 2}=\mathrm{on}$ state resistance of switch SW2; $V_{d}=$ diode forward voltage; $V_{L}=$ voltage across the inductor; $I_{b}=$ battery current; $I_{\text {load }}=$ load current; $I_{c}=$ current through filter capacitor; $V c=$ filter capacitor voltage.

\section{RESULTS AND DISCUSSION}

The simulation is carried out for different driving modes of vehicle by considering different driving cycles. The results are tabulated in Table 4 . The bus voltage is regulated around 400V and the SOC of battery is well within the limits. The simulation graphs are shown in Figure 14 and Figure15. The selection of battery rating depends on the type of driving cycle. If the battery recovers more energy during deceleration, the effective energy consumed by it reduces. Consequently, the range of the vehicle increases. This is shown in the Figure 16. The $\mathrm{C}$ rating of the battery is maintained $2 \mathrm{C}$ during discharge of battery.

Table 4. Simulation results of BESS

\begin{tabular}{lcccc}
\hline Type & Range $(\mathrm{km})$ & $\begin{array}{l}\text { C rate during } \\
\text { discharge }\end{array}$ & $\begin{array}{l}\text { C rate during } \\
\text { charge }\end{array}$ & $\begin{array}{l}\text { Energy recovered } \\
(\mathrm{wh})\end{array}$ \\
\hline $\begin{array}{l}\text { variable } \\
\text { speed cycle }\end{array}$ & 363 & 1.4 & 2.2 & 252 \\
$\begin{array}{l}\text { constant } \\
\text { speed cycle }\end{array}$ & 239 & 1.35 & 0 & 0 \\
Tata1 & 255 & 1 & 0.7 & 92 \\
Tata2 & 262 & 1.9 & 1.3 & 128 \\
UDDS & 240 & 1.1 & 0.4 & 87 \\
EUDC & 237 & 1.98 & 0.46 & 92 \\
Trial cycle & 278 & 1.14 & 0.88 & 140 \\
\hline
\end{tabular}
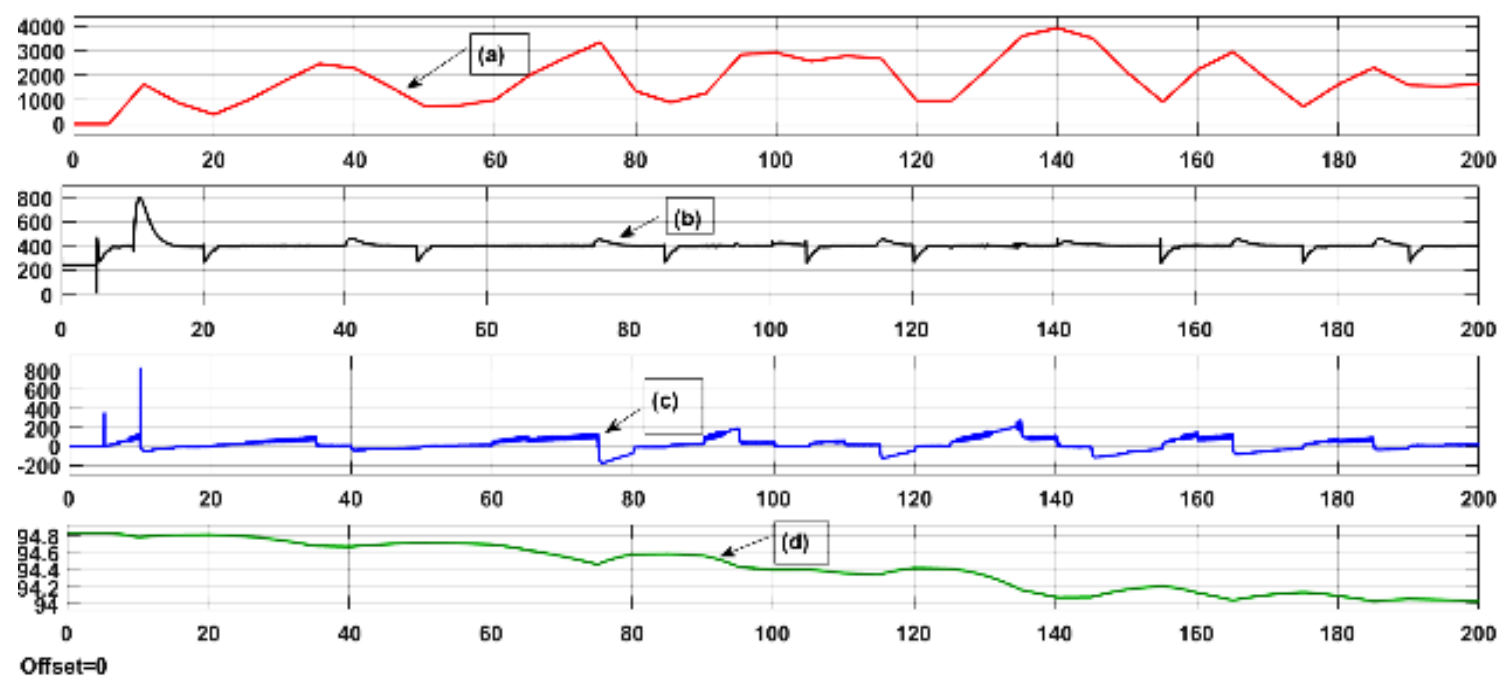

Figure 14. (a) Driving cycle; (b) Bus voltage; (c) Battery current: (d) SOC of battery 


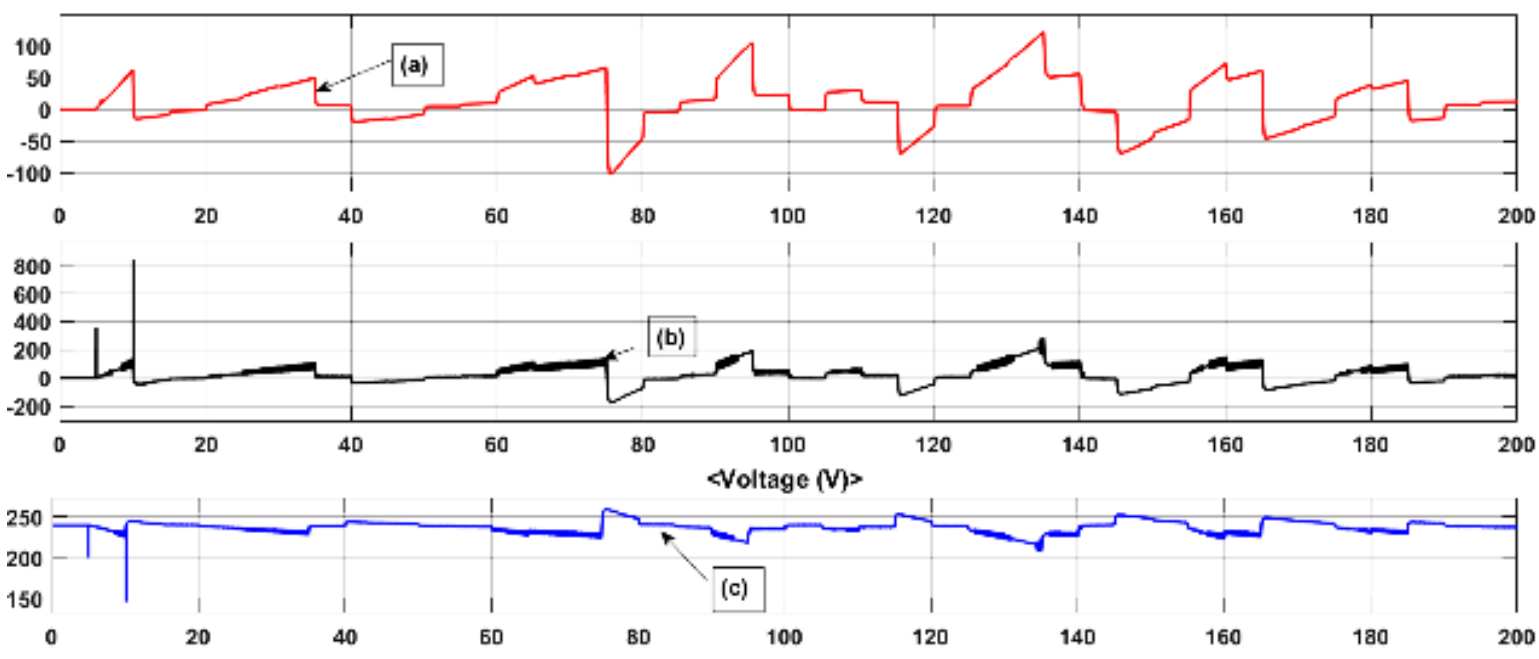

Figure 15. (a) Load current; (b) Battery current; (c) Battery voltage

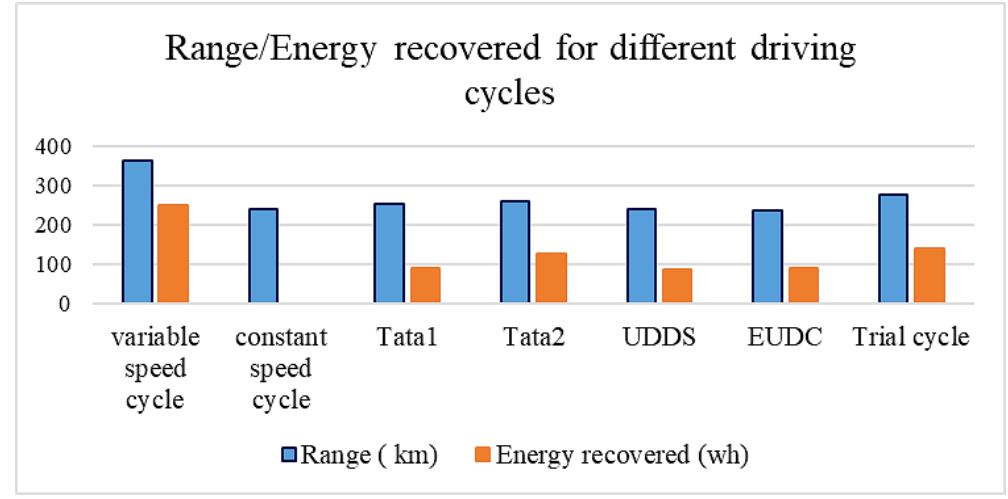

Figure 16. Graph showing the range covered and energy recovered for different driving cycles

\section{CONCLUSION AND FUTURE SCOPE}

The behavior of the battery for urban and highway driving conditions is studied. The motor rating is selected based on the performance requirement of vehicle and its performance is tested for urban and highway driving cycles. The Simulink model of IM is built and by applying V/f control and the current load information is obtained. The current load emulates the vehicle load in this work. The battery rating is selected depending on the peak and average current requirement from the vehicle and the range the vehicle it has to cover.

The hybrid energy storage system (HESS) can be thought of where battery is interfaced with ultracapacitor via a power converter. A proper control strategy can be adopted to optimally share the load between them. The burden on the battery can be reduced and range of the vehicle can be increased.

\section{REFERENCES}

[1] Mehrdad Ehsani, Ali Emadi, and Yimin Gao, "Modern electric, hybrid electric, and fuel cell vehicles," CRC Press, 2nd edition, 2011.

[2] NITI Aayog Report, "Global Mobility Summit," September 7 \& 8, 2018, available online at https://niti.gov.in/writereaddata/files/document_publication/EV_report.pdf.

[3] National Electric Mobility Mission Plan 2020 by Government of India, available online at https://www.drishtiias.com/pdf/national-electric-mobility-mission-2020.pdf.

[4] Alexandre Ravey, Nicolas Watrin, Benjamin Blunier, David Bouquain and Abdellatif Miraoui, "Energy-sourcesizing methodology for hybrid fuel cell vehicles based on statistical description of driving cycles", IEEE Transactions on Vehicular Technology, vol. 60, no. 9, November 2011. pp. 4164-4174, doi: 10.1109/TVT.2011.2158567. 
[5] Junyi Shen, Amin Hasanzadeh and Alireza Khaligh, "Optimal power split and sizing of hybrid energy storage system for electric vehicles," IEEE Transportation Electrification Conference and Expo, Dearborn, MI, 2014, pp:1-6, doi: 10.1109/ITEC.2014.6861861.

[6] Chandra Shekher Purohit, Geetha M, Padmanaban Sanjeevikumar, Pandav Kiran Maroti, Shruti Swami, and Vigna $\mathrm{K}$. Ramachandaramurthy, "Performance analysis of DC/DC bidirectional converter with sliding mode and pi controller", International Journal of Power Electronics and Drive System (IJPEDS), vol. 10, no. 1, pp. 357-365, March 2019, doi: 10.11591/ijpeds.v10.i1.pp357-365.

[7] Wael A. Salah, Mahmoud A. M. Albreem, Basim Alsayid, Basem Abu Zneid, Mutasem Alkhasawneh, Anwar AlMofleh, et al., "Electric vehicle technology impacts on energy," International Journal of Power Electronics and Drive System (IJPEDS), vol. 10, No. 1, pp.1-9, March 2019, doi: 10.11591/ijpeds.v10.i1.pp1-9.

[8] M. Kavitha, V. Elanangai, S. Jayaprakash, and V. Balasubramanian, "Development of regenerative braking concept for electric vehicle enhanced with bidirectional converter," International Journal of Power Electronics and Drive System (IJPEDS), vol. 9, no. 4, pp. 1584-1590, December 2018, doi: 10.11591/ijpeds.v9.i4.pp1584-1590.

[9] Mahmoudi Chokri, Flah Aymen, and Sbita Lassaad, "Smart database concept for power management in an electrical vehicle," International Journal of Power Electronics and Drive System (IJPEDS), vol. 10, No. 1, pp. 160-169, March 2019, doi: 10.11591/ijpeds.v10.i1.pp160-169.

[10] Enwelum I. Mbadiwe, Erwan Sulaiman, Zarafi Md. Ahmad, and M. F. Omar, "Permanent magnet flux switching motor technology as a solution for high torque clean electric vehicle drive," International Journal of Power Electronics and Drive System (IJPEDS), vol. 10, No. 2, pp. 575-584, June 2019, doi: 10.11591/ijpeds.v10.i2.pp575-584.

[11] Mustafa Abbas Fadel Al-Qaisi, Mohanad A. Shehab, Ammar Al-Gizi, and Mohammed Al-Saadi, "High performance DC/DC buck converter using sliding mode controller," International Journal of Power Electronics and Drive System (IJPEDS), vol. 10, No. 4, pp.1806-1814, December 2019, doi: 10.11591/ijpeds.v10.i4.pp18061814.

[12] W. Abitha Memala et.al, "DC-DC converter-based power management for go green applications," International Journal of Power Electronics and Drive System (IJPEDS), vol. 10, No. 4, December 2019, pp. 2046-2054.

[13] Soeprapto, Rini Nur Hasanah, Taufik, "Battery management system on electric bike using lithium-ion 18650," International Journal of Power Electronics and Drive System (IJPEDS), vol. 10, No. 3, Sep 2019, pp. 1529-1537.

[14] Chaymae Laoufi et.al, "New model of electric traction drive based sliding mode controller in field-oriented control of induction motor fed by multilevel inverter," International Journal of Power Electronics and Drive System (IJPEDS), vol. 11, No. 1, March 2020, pp. 242-250.

[15] Bindu R and Sushil Thale, "Sizing of hybrid energy storage system and propulsion unit for electric vehicle," 2017 IEEE Transportation Electrification Conference (ITEC-India), Pune, 2017, pp. 1-6, doi: 10.1109/ITECIndia.2017.8333846.

[16] Ricardo de Castro, Cláudio Pinto, Rui Esteves Araújo, Pedro Melo, and Diamantino Freitas, "Optimal sizing and energy management of hybrid storage systems," 2012 IEEE Vehicle Power and Propulsion Conference, 2012, pp. 32-326, doi: 10.1109/VPPC.2012.6422679.

[17] Zhuang Ji-Hui, Xie Hui, and Yan Ying, "Remote self-learning of driving cycle for electric vehicle demonstrating area," 2008 IEEE Vehicle Power and Propulsion Conference, Harbin, 2008, pp. 1-4, doi: 10.1109/VPPC.2008.4677700.

[18] Amir Ahmed, and Dikki D Bhutia, "Propulsion system design and sizing an electric vehicle," International Journal of Electronics and Electrical Engineering, vol. 3, no. 1, pp. 14-18, 2015, doi: 10.12720/ijeee.3.1.14-18

[19] T. Porselvi1, Srihariharan M. K, Ashok J, and Ajith Kumar S, "Selection of power rating of an electric motor for electric vehicles," International Journal of Engineering Science and Computing, vol 7, pp. 6469-6472, 2017.

[20] Md. Junaid Akhtarl R. K. Behera S. K. Parida, "Propulsion system design of electric vehicle," International Conference on Power Electronics Systems and Applications (PESA), 2015, pp. 1-5, doi: 10.1109/PESA.2015.7398900.

[21] Rui Esteves Araújo, Ricardo de Castro, Cláudio Pinto, Pedro Melo and Diamantino Freitas, "Combined sizing and energy management in EVs with batteries and supercapacitors," IEEE Transactions on Vehicular Technology, 2014, pp. 3062 -3076, doi 10.1109/TVT.2014.2318275.

[22] Z. Zhou, B. Wang, Y. Guo and Y. Zhang, "Blockchain and computational intelligence inspired incentivecompatible demand response in internet of electric vehicles," IEEE Transactions on Emerging Topics in Computational Intelligence, vol. 3, no. 3, pp. 205-216, June 2019, doi: 10.1109/TETCI.2018.2880693.

[23] Jyothi P Phatak, L. Venkatesha, and C.S Raviprasad, "An alternative procedure for selection of induction motor for electric vehicle application,” Journal of Computational and Theoretical Nanoscience, vol 16, no. 8, pp. 3351-3358, 2019, doi: doi.org/10.1166/jctn.2019.8219.

[24] L Umanand, "Power electronics essentials \& applicaions," Wiley India Pvt Ltd. New Delhi, 2009.

[25] Marian K. Kazimierczuk, "Pulse-width modulated DC-DC power converters," A John Wiley and Sons, Ltd, Publication, 2008 edition. 


\section{BIOGRAPHIES OF AUTHORS}
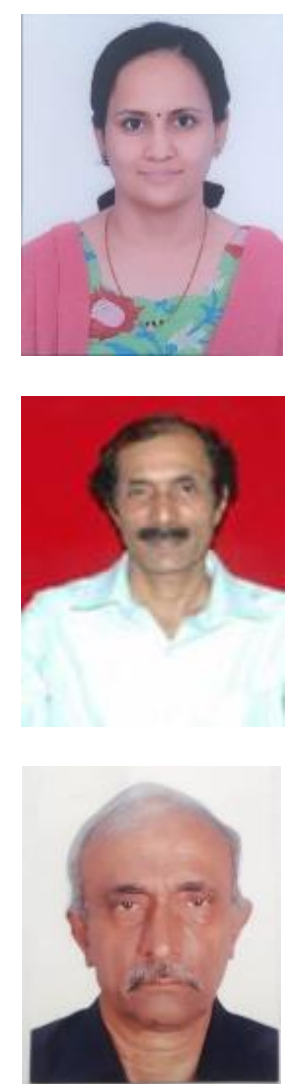

C. S Raviprasad, proprietor Tarun Technology Design Consultant, has a pure science Bsc degree and Electrical Engineering BE degree from Bangalore University. Aged 64 years, has 42 years of experience in design, analysis, production, quality systems, and application Engineering of Rotating machines like DC commutator motors, Alteranting Current (AC) motors, Permanent Magnet AC and DC motors. He has developed special purpose motors in steel, cement, automobile and traction applications, traction repair and traction coil making. Has earlier worked in leading companies like M/s BHEL ISG, M/s Kirloskar Electric, Integrated Electric Company in various capacities. 